\title{
Cloning structural genes for Treponema pallidum immunogens and characterisation of recombinant treponemal surface protein, $\mathrm{P} 2 *(\mathrm{P} 2$ star)
}

\author{
K M PETERSON, J B BASEMAN, J F ALDERETE \\ From the Department of Microbiology, The University of Texas Health Science Center at San Antonio, San \\ Antonio, Texas, USA
}

SUMMARY A genomic library consisting of partially digested 10 to 20 kilobase pair fragments of Treponema pallidum deoxyribonucleic acid (DNA) was constructed using bacteriophage lambda EMBL-3 as the vector. Positive clones expressing $T$ pallidum antigens were detected with sera from experimentally infected rabbits. Treponemal proteins ranging in molecular weight from 37000 daltons to 120000 daltons were identified by sodium dodecyl sulphate-polyacrylamide gel electrophoresis and immunoblotting of phage lysate proteins. One recombinant phage was examined further and contained an insert encoding a prominent treponemal 37000 dalton protein. The recombinant protein was not recognised by antiserum directed against a fibronectin binding treponemal adhesin that contained the same electrophoretic mobility. Neither did antibody to the recombinant 37000 dalton protein react with any treponemal proteins purified by fibronectin affinity chromatography. The recombinant protein in Escherichia coli lysates was labelled P2* (P2 star) to differentiate it from the comigrating adhesin protein called P2. Native P2* protein was present on $T$ pallidum surfaces as shown by radioimmunoprecipitation assays with extrinsically labelled organisms. A cross reactive molecule like P2* was not synthesised by the avirulent spirochaete, $T$ phagedenis biotype Reiter, which indicated that $\mathrm{P} 2 *$ is a protein specific to virulent $T$ pallidum organisms. Finally, only sera of patients with primary syphilis possessed appreciable concentrations of antibody to recombinant P2* protein.

Infection with Treponema pallidum elicits the production of "protective" antibodies that reduce, delay, or abrogate the development of lesions in experimental animals. ${ }^{1-5}$ The function of these immunoglobulins in protection is uncertain, as organisms persist in the presence of high titred antibodies to $T$ pallidum. ${ }^{3}$ The role of cell mediated immune effectors in. response to $T$ pallidum infection is also poorly understood. ${ }^{6}$

An active area of research in recent years has been the evaluation of host humoral responses to specific treponemal components during syphilis. ${ }^{7-12}$ Radioimmunoprecipitation electrophoresis and immunoblot assays, for example, have shown numerous immunogenic treponemal proteins. The biological

Address for reprints: Dr John F Alderete, Department of Microbiology, The University of Texas Health Science Center at San Antonio, 7703 Floyd Curl Drive, San Antonio, Texas 78284, USA

Accepted for publication 28 November 1986 function and location of these immunogens, however, have not been assessed, partly because this pathogen is not satisfactorily cultivable in vitro. ${ }^{13}$ Recombinant deoxyribonucleic acid (DNA) technology ${ }^{14-18}$ is therefore necessary to obtain sufficient quantities of parasite antigen. ${ }^{19}$ This may permit a detailed analysis of the role, if any, of precise treponemal proteins in $T$ pallidum virulence and in the pathogenesis of syphilis. In this study, we describe the cloning and expression of several genes for treponemal proteins. We show the highly immunogenic nature and surface disposition of a recombinant 37000 dalton protein, and discuss our results in terms of the biology of the syphilis spirochaete.

\section{Materials and methods}

BACTERIA

The Nichols strain of $T$ pallidum was inoculated intratesticularly into New Zealand white rabbits as described previously. ${ }^{20}$ Treponemes were harvested 
from minced testicular tissue excised at peak orchitis (7-11 days after inoculation) by shaking in $15 \mathrm{ml}$ of a salts-glucose medium under reducing conditions for 20 minutes at $34^{\circ} \mathrm{C} .{ }^{72122}$ The treponemal suspension containing $1 \times 10^{8}$ to $4 \times 10^{8}$ organisms $/ \mathrm{ml}$ was centrifuged twice at room temperature at $500 \times g$ for 15 minutes followed by centrifugation on a cushion of $0.8 \%$ Methacel (Dow Corning, Midland, Mississippi, USA) and $50 \%$ Hypaque (Winthrop Labs, New York) at $650 \times g$ for 20 minutes. The supernate containing highly motile treponemes was centrifuged at $17000 \times g$ to pellet the organisms. The treponemal pellets were stored at $-70^{\circ} \mathrm{C}$ until needed for DNA extraction or for preparing total proteins. ${ }^{23}$

Escherichia coli strains LE $392^{24}\left(\mathrm{~F}^{-}\right.$, hsdR514, supE44, supF58, lac Y, galK2, galT22, metB, trpR55, lambda ${ }^{-}$) and $\mathrm{NM} 539^{25}$ (supF, hsdR [P2 cox]) (Promega biotec) were grown in Luria broth. ${ }^{24}$

\section{SERA}

Serum obtained from rabbits inoculated intratesticularly with live treponemes ${ }^{2} 722$ was extensively adsorbed with $E$ coli LE 392 before being used for clone bank screening. Serum samples from patients with syphilis were gifts from Sandra Larsen of the Center for Disease Control, Atlanta, Georgia, and have been characterised by us. ${ }^{26}$ Serum samples from uninfected rabbits and from people without a history of sexually transmitted diseases were used as controls.

\section{DNA EXTRACTION FROM $T$ PALLIDUM}

About $1 \times 10^{11}$ washed pelleted spirochaetes were resuspended in $5 \mathrm{ml}$ of $50 \mathrm{mmol} / 1$ TRIS and hydrochloric acid $(\mathrm{HCl})$ buffer, $\mathrm{pH} 8 \cdot 0$, containing $50 \mathrm{mmol} / \mathrm{l}$ ethylenediaminetetra-acetic acid (EDTA). ${ }^{27}$ A volume of $5 \mathrm{mg}$ lysozyme in $0.5 \mathrm{ml}$ of $250 \mathrm{mmol} / \mathrm{l}$ TRIS-HCl, $\mathrm{pH} 8.0$, was then added, and the reaction kept on ice for 45 minutes. Next, $1 \mathrm{ml}$ of disrupting buffer $(0.5 \%$ sodium dodecyl sulphate (SDS), $50 \mathrm{mmol} / 1$ TRIS-HCl, $400 \mathrm{mmol} / 1$ EDTA, and $1 \mathrm{mg} / \mathrm{l}$ proteinase $\mathrm{K}$ ), $\mathrm{pH} 7 \cdot 5$, was added, and the mixture was incubated for one hour at $50^{\circ} \mathrm{C}$ with occasional shaking. This material was then extracted three times with TRIS buffered phenol. ${ }^{24}$ The aqueous layer was precipitated with $15 \mathrm{ml}$ cold ethanol in $300 \mathrm{mmol} / 1$ sodium acetate. The precipitate was resuspended in $5 \mathrm{ml}$ TRIS-EDTA buffer $(50 \mathrm{mmol} / 1$ TRIS-HCl and $1 \mathrm{mmol} / \mathrm{l} \mathrm{EDTA}$ ), $\mathrm{pH} 8 \cdot 0$, containing $200 \mu \mathrm{g}$ DNase free RNase/ml (Boehringer Mannheim). After overnight incubation at $4^{\circ} \mathrm{C}$, the material was extracted twice with $5 \mathrm{ml}$ chloroform, and the DNA was precipitated with ethanol and sodium acetate. ${ }^{24}$ Finally, the DNA was resuspended in TRISEDTA buffer, $\mathrm{pH} 8 \cdot 0$, at a concentration of $1 \mathrm{mg} / \mathrm{ml}$.

\section{CONSTRUCTION OF T PALLIDUM GENOMIC}

\section{LIBRAR Y}

A bacteriophage lambda library of $T$ pallidum DNA was prepared as described in fig 1 . Briefly, $T$ pallidum DNA was partially digested with BamHI restriction endonuclease (Boehringer Mannheim) and fractionated by centrifugation on a linear $10 \%$ to $40 \%$ sucrose gradient. ${ }^{24}$ DNA fragments containing 10 to 20 kilobase pairs were pooled and dialysed against TRIS-EDTA buffer, $\mathrm{pH} 8 \cdot 0$, followed by phenol extraction $^{24}$ and ethanol precipitation. ${ }^{24}$

EMBL-3 vector DNA digested with BamHI and EcoRI endonuclease was ligated to the sized $T$ pallidum fragments and packaged to produce viable phages using a lambda in vitro packaging system (Promega Biotec).

\section{IMMUNOLOGICAL SCREENING OF CLONE BANK}

Recombinant phage plaque material was immobilised on nitrocellulose discs. These discs were placed in TRIS buffered saline $(500 \mathrm{mmol} / 1$ sodium chloride, and $20 \mathrm{mmol} / 1$ TRIS-HCl) with $1 \%$ bovine serum albumin, $\mathrm{pH} 7 \cdot 4$, for two hours at room temperature and then incubated with adsorbed syphilitic rabbit serum at 1:50 dilution in TRIS buffered saline and 5\% non-fat dried milk. ${ }^{1428}$ The nitrocellulose was washed three times for 15 minutes with TRIS buffered saline, and horseradish peroxidase conjugated goat anti-rabbit IgG (BioRad) diluted 1:2000 in TRIS buffered saline and $5 \%$ milk was then added. The blots were washed three additional times before substrate was added. Positive clones were spotted in duplicate on $E$ coli, transferred to nitrocellulose, and tested again for antibody reactivity to insure the isolation of clones producing positive signals.

\section{RADIOIMMUNOPRECIPITATION ASSAY, SODIUM} DODECYL SULPHATE-POLYACRYLAMIDE GEL ELECTROPHORESIS (SDS-PAGE), AND

IMMUNOBLOTTING

Detergent solubilised treponemal proteins were radioimmunoprecipitated under conditions detailed previously. ${ }^{7}$ Protein preparations subjected to SDSPAGE were immunoblotted as described previously. ${ }^{714212229}$ Proteins from recombinant $E$ coli were prepared for SDS-PAGE by scraping the soft agarose overlays from $1 \mathrm{~cm}$ diameter phage plaques and boiling them in SDS-PAGE dissolving buffer.

\section{ELUTION OF ANTIBODY TO T PALLIDUM FROM PHAGE LYSATES}

Nitrocellulose discs containing proteins from plate lysates of individual recombinant clones were incubated overnight at $4^{\circ} \mathrm{C}$ with adsorbed syphilitic rabbit serum and then washed three separate times with TRIS buffered saline. Bound antibodies were eluted 


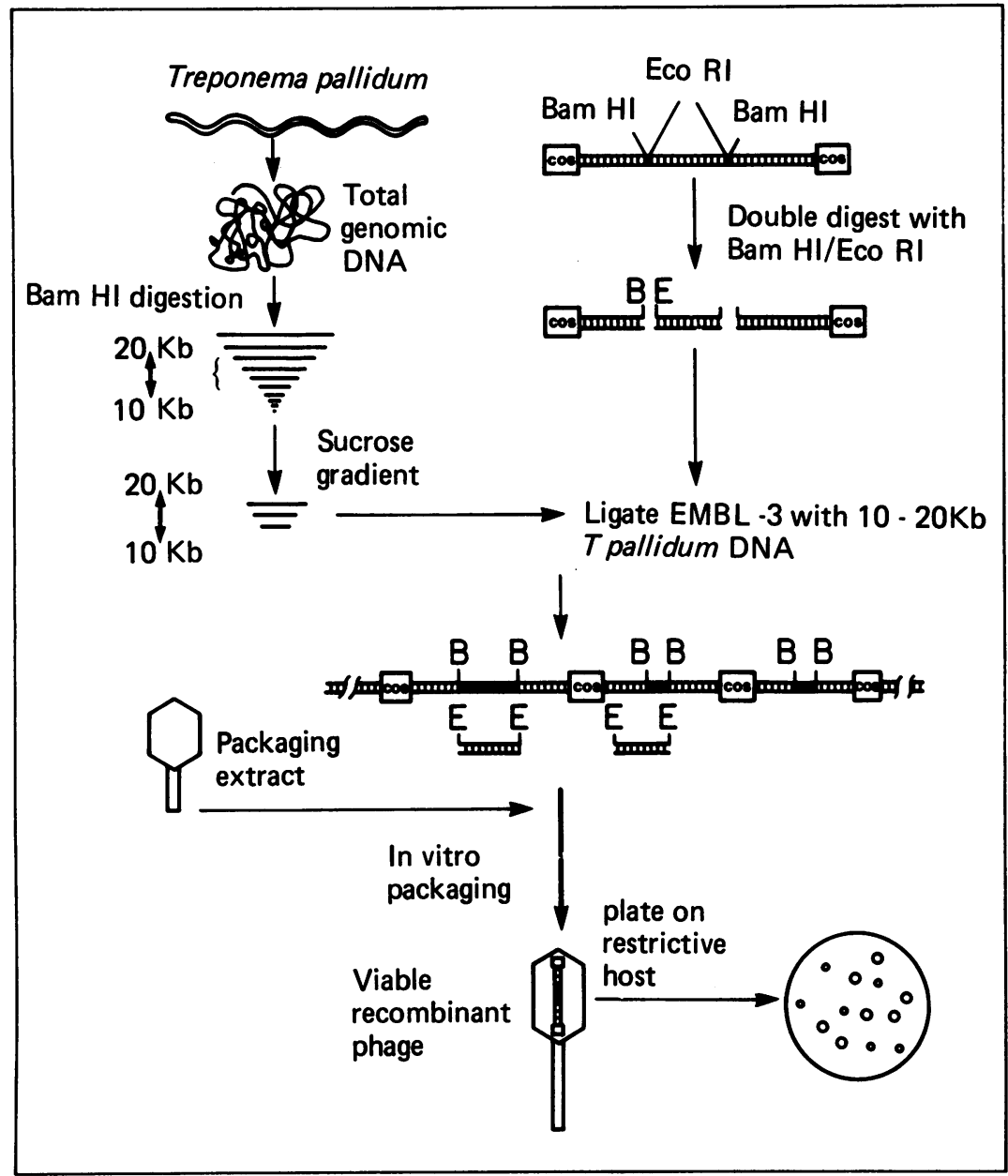

Fig 1 Schematic representation of cloning strategy used to generate Treponema pallidum library.

with $5 \mathrm{ml}$ of a solution of $100 \mathrm{mmol} / \mathrm{l}$ glycine, $20 \mathrm{mmol} / 1 \mathrm{magnesium}$ acetate, and $50 \mathrm{mmol} / \mathrm{l}$ potassium chloride, $\mathrm{pH} 2 \cdot 6$, for two hours at room temperature and dialysed for 12 hours against two changes of TRIS buffered saline before being stored at $-20^{\circ} \mathrm{C} .{ }^{14}$

\section{DOT BLOT ANALYSIS OF B5 RECOMBINANT PHAGE EXPRESSING P2*}

Phages were spotted on to $E$ coli, transferred to nitrocellulose, and tested for reactivity to serum from patients with syphilis. ${ }^{26}$ Individual nitrocellulose immobilised plaques were cut into $2 \mathrm{~cm}$ squares and placed in 24 well culture plates. A volume of $1 \mathrm{ml}$ human syphilitic serum diluted 1:50 in TRIS buffered saline and 5\% milk was added to the squares followed by $100 \mu 1 E$ coli disrupted in a French pressure cell. Incubation was carried out at $4^{\circ} \mathrm{C}$ overnight, followed by three washes with TRIS buffered saline. Horseradish peroxidase conjugated goat anti-human IgG (Cappel, Cochranville, Pennsylvania) diluted 1:500 in TRIS buffered saline and $5 \%$ milk was added for three hours at $4^{\circ} \mathrm{C}$. The dot blots were washed again and developed as described above. Reactivity was compared with that of control squares incubated with second antibody, alone or with normal human serum.

PURIFICATION OF TREPONEMAL PROTEINS BINDING TO FIBRONECTIN

Treponemal proteins $\mathbf{P 1}, \mathbf{P} 2$, and $\mathbf{P} 3$ were purified by fibronectin-Sepharose affinity chromatography as described previously. ${ }^{23}$ Briefly, $2 \times 10^{10}$ freshly har- 
vested spirochaetes were resuspended in $100 \mu \mathrm{l}$ of $10 \%$ Zwittergent 3-12 (Z (3-12); CalbiochemBehring) detergent. ${ }^{23}$ After being homogenised and clarified, the extract was diluted in phosphate buffered saline (PBS) to give a final concentration of $0.05 \% \mathrm{Z}(3-12)$. This soluble preparation was then incubated with $500 \mu$ l of fibronectin-Sepharose ${ }^{23}$ for six hours at room temperature with gentle rocking. The beads were then washed with 100 volumes of PBS and $0.05 \% \mathrm{Z}(3-12)$. Treponemal material adherent to fibronectin (P1, P2, and P3) was released by boiling in $1 \mathrm{ml}$ of electrophoresis solubilising buffer ${ }^{7}$ for three minutes. The Sepharose was pelleted by centrifugation, and the resulting supernate subjected to SDSPAGE for immunological analysis.

\section{Results}

ESTABLISHING T PALLIDUM GENOMIC LIBRARY

Figure 1 shows the scheme employed for obtaining a genomic library of $T$ pallidum DNA. We chose EMBL-3 bacteriophage as a cloning vehicle for $T$ pallidum DNA because of its high cloning efficiency, its large insert size (10-20 kilobase pairs), and its ability to minimise non-recombinant background phages. This system generated a library of over 100000 recombinant phages for further analysis.

Figure 2 shows an immunoblot of the recombinant treponemal proteins from representative phage clones producing signals. Some clones produced several distinct treponemal polypeptides, as evidenced by mul-

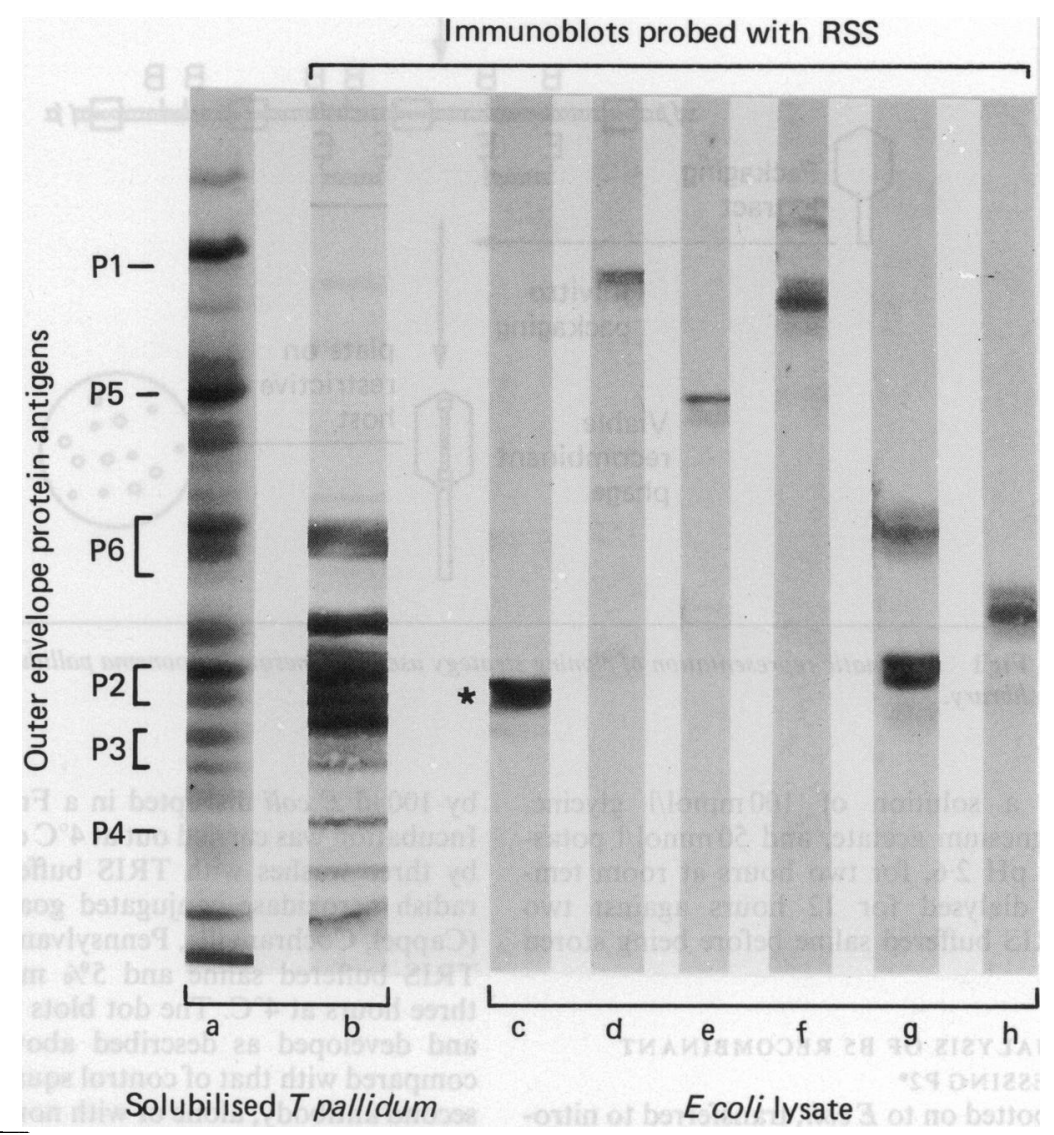

Fig 2 Immunoblot identification of Treponema pallidum proteins present in recombinant phage plaques. Profile of solubilised treponemal proteins stained with Coomassie brilliant blue after SDS-PAGE (lane a). Same proteins transferred to nitrocellulose for detection by syphilitic rabbit serum (lane $b$ ). Recombinant protein bands from lysates of individual phage clones reactive with syphilitic rabbit serum adsorbed with Escherichia coli (lanes $c-h){ }^{*}=$ protein of clone B5 called P2* (P2 star). 
tiple bands from the same lysate preparation using adsorbed syphilitic rabbit serum (lanes $d, f$, and $g$ ), whereas other lysates yielded a single protein band. Adsorbed syphilitic rabbit serum did not recognise any rabbit testicular tissue proteins or control phage lysates. It was important that syphilitic rabbit serum antibodies eluted from individual nitrocellulose blots of these six phage lysates (fig 2 , lanes $\mathrm{c}$ to $\mathrm{h}$ ) detected $T$ pallidum proteins with the same electrophoretic mobilities. In control experiments, syphilitic rabbit serum antibodies eluted from non-recombinant phage blots detected no treponemal proteins. Normal rabbit serum did not react with recombinant phage lysates or immunoblots of total treponemal proteins. These data, therefore, show the cloning of structural genes for these various $T$ pallidum proteins using these experimental conditions.

\section{ANALYSIS OF RECOMBINANT 37000 DALTON $T$ PALLIDUM PROTEIN DESIGNATED P2*}

We then characterised further a 37000 dalton recombinant protein of phage clone B5 (fig 2, lane c) because it possessed a relative molecular weight identical to that of the treponemal proteins that bound to fibronectin, which had been designated P2 in earlier studies. ${ }^{21-23}$ Antibodies were eluted from nitrocellulose blots of phage lysates containing the $\mathbf{3 7 0 0 0}$ dalton recombinant protein. The eluted antibodies, however, failed to recognise by immunoblot any of the purified treponemal adhesins (data not shown). ${ }^{23}$ The recombinant protein also failed to bind to fibronectin-Sepharose, ${ }^{23}$ and antibodies to the treponemal fibronectin binding adhesins did not react with the 37000 dalton recombinant protein. These data indicated that the recombinant 37000 dalton protein designated P2* can be differentiated from the comigrating adhesin molecule $\mathrm{P} 2 .^{23}$

Native $T$ pallidum was then compared with the recombinant $\mathrm{P}^{*}$ proteins. As can be seen in fig 3 , syphilitic rabbit serum antibody eluted from nitrocellulose blots of phage lysates with P2* detected a single band in the total treponemal protein preparation (lane c). It also identified a protein band of the same size as recombinant P2* (lane b). Syphilitic rabbit serum adsorbed on nitrocellulose blots containing P2* phage lysate also resulted in decreased reactivity to the 37000 dalton migrating region of the immunoblot (lane e). Syphilitic rabbit serum adsorbed with control phage lysates was unchanged (lane d), and, as expected, normal rabbit serum did not react with the recombinant 37000 dalton protein or treponemal proteins. ${ }^{7}$ These data show the immunogenic nature of $\mathrm{P}^{*}$ and confirm the cloning of the structural gene for this protein antigen.
DEMONSTRATION OF THE SURFACE LOCATION OF NATIVE P2*

Figure 4 shows the radioimmunoprecipitation of radioiodinated $\mathrm{P} 2 *$ from a detergent extract of iodinated $^{21}$ treponemes (lane d) using antibody eluted from phage blots containing recombinant 37000 dalton protein. Furthermore, syphilitic rabbit serum adsorbed against blots of recombinant P2* showed diminished band intensity for iodinated P2* when compared with other precipitated surface proteins (lane c) or when unadsorbed syphilitic rabbit serum was used (lane b). It was important that eluted antibody adsorbed against live $T$ pallidum organisms resulted in no detectable iodinated P2* (data not shown), confirming the surface disposition of this treponemal protein. As expected, normal rabbit serum did not immunoprecipitate iodinated treponemal proteins.

\section{REACTIVITY OF HUMAN SYPHILITIC SERA WITH} RECOMBINANT P2*

We then tested by immunoblot analysis various serum samples from patients with primary, secondary, and latent syphilis and control samples from uninfected people for their reactivity to recombinant 37000 dalton protein. Using 1:10 dilutions of the various sera, those from five out of six patients with primary syphilis were highly reactive and one was weakly reactive with recombinant $\mathbf{P} 2^{*}$, whereas only one of five with secondary syphilis and none of six with latent syphilis possessed antibody to detect this treponemal surface component.

\section{Discussion}

In this report we show the generation of a gene library of $T$ pallidum DNA in bacteriophage lambda in which recombinant treponemal proteins were recognised by antibodies from experimentally infected animals. The observation that antibodies affinity purified from nitrocellulose blots of recombinant proteins recognised $T$ pallidum proteins of the same electrophoretic mobility (fig 3 ) suggested that the intact structural genes for these respective treponemal products had been cloned.

A phage clone encoding the 37000 dalton polypeptide designated $\mathrm{P} 2 *$ was chosen for further study because it possessed a molecular mass similar to that of a treponemal adhesin previously implicated as a $T$ pallidum fibronectin binding protein. ${ }^{23}$ Antibodies specific for the recombinant 37000 dalton protein, however, did not recognise $T$ pallidum adhesins isolated by fibronectin affinity chromatography. Thus the recombinant 37000 dalton protein represents a distinct immunogen with the same electrophoretic mobility as the adhesin, which suggests that antibody 


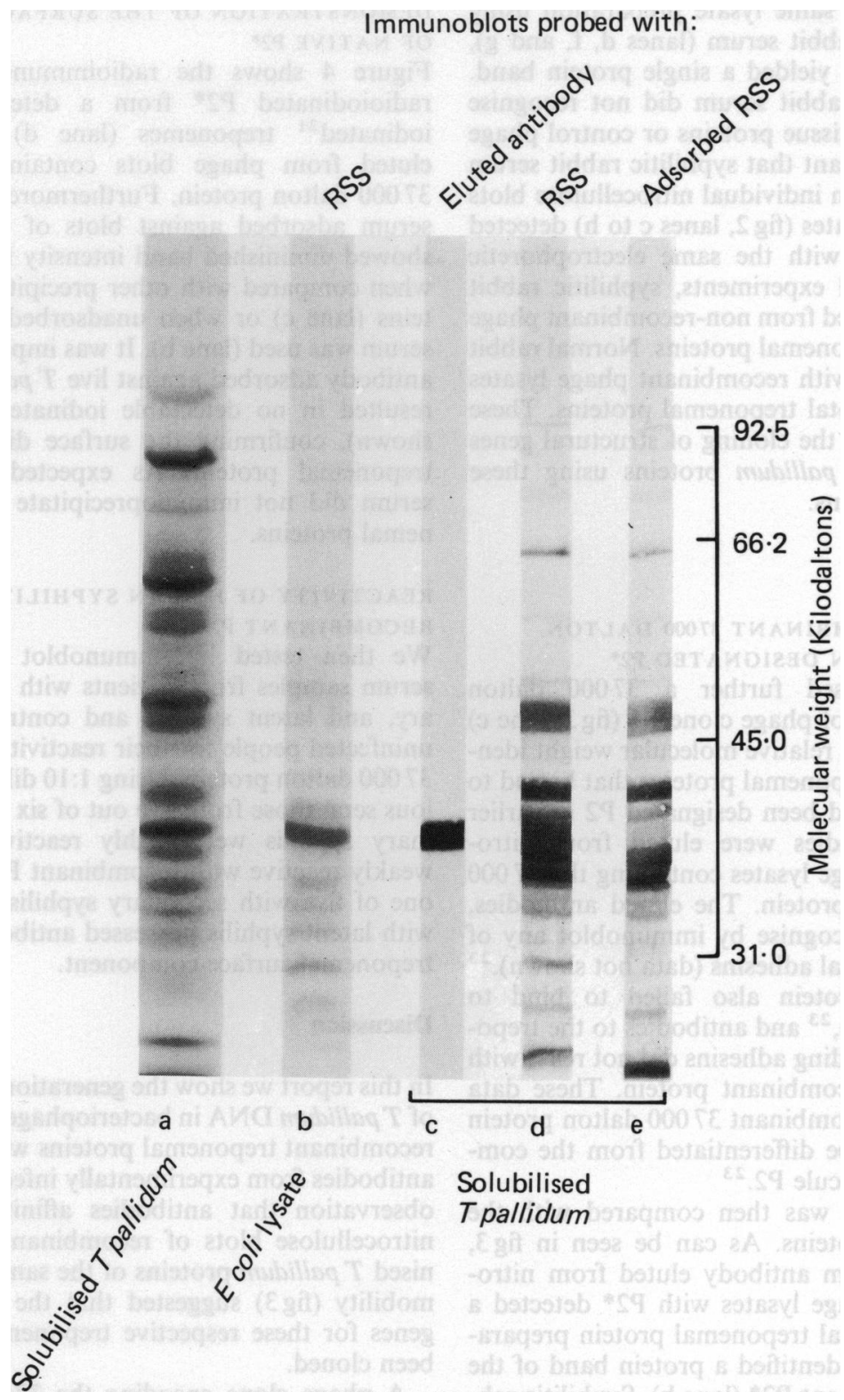

Fig 3 Immunoblot analysis of recombinant 37000 dalton Treponema pallidum protein $P 2^{*}$. Stained protein pattern of solubilised $T$ pallidum proteins after SDS-PAGE (lane a). Recombinant P2* phage product in Escherichia coli lysates detected by rabbit syphilitic serum (lane $b$ ). Treponemal protein identified by antibodies eluted from recombinant phage plaques containing $P 2^{*}$ (lane $c$ ). $T$ pallidum protein antigens detected by syphilitic rabbit serum (lane d) and by syphilitic rabbit serum adsorbed against nitrocellulose blots containing recombinant $P 2^{*}$ protein (lane $e$ ). 


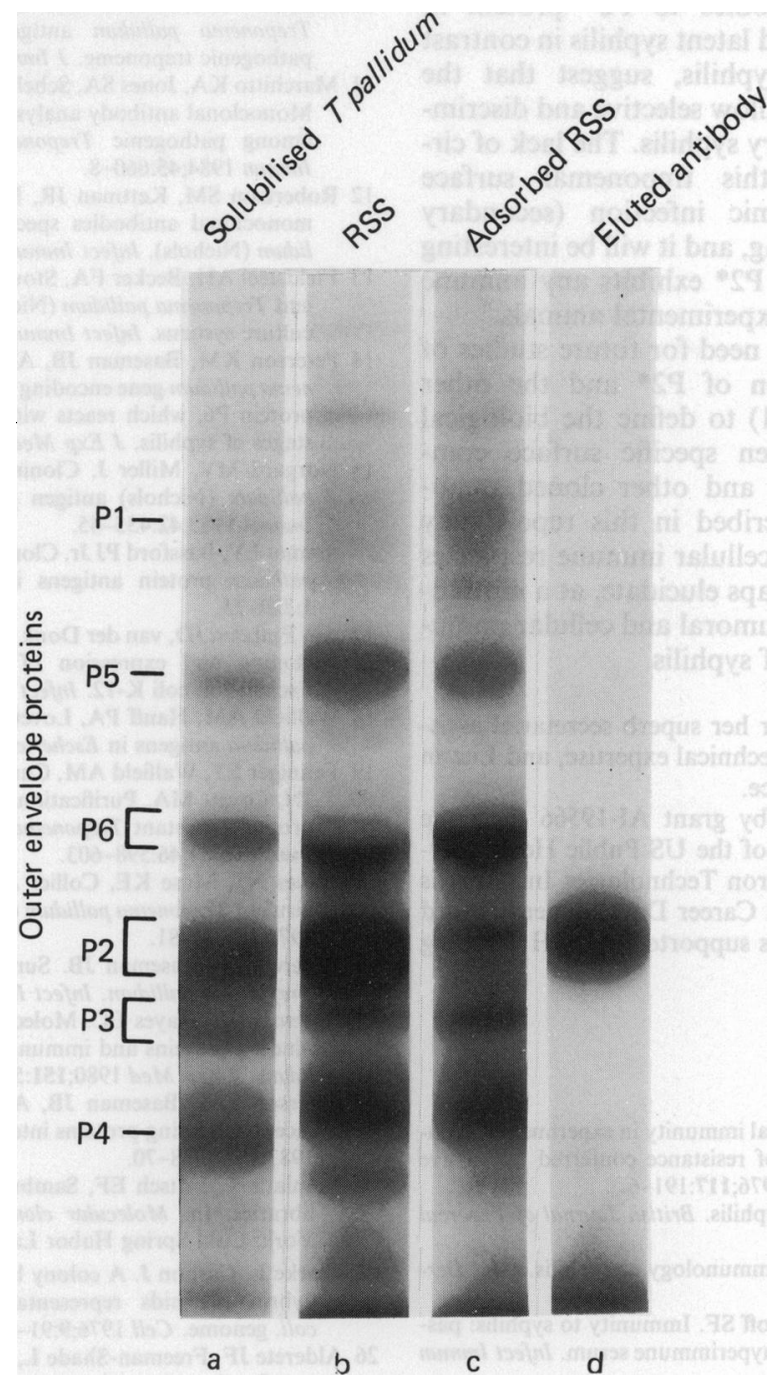

Fig 4 Surface location of $P 2^{*}$ shown by radioimmunoprecipitation assay. Surface radioiodinated $T$ pallidum were solubilised with detergent and incubated with rabbit syphilitic serum (lane b), syphilitic rabbit serum adsorbed against nitrocellulose blots of phage lysates containing P2* (lane $c$ ), and antibody to syphilitic rabbit serum eluted from blots of recombinant $P 2^{*}$ (lane d).

Autoradiogram of detergent solubilised $T$ pallidum proteins (lane a).

reactive proteins of this molecular weight are not solely the adhesins as suggested previously, ${ }^{730}$ thus differentiating the rabbit and human antibody produced during infection with $\mathbf{P} 2 *$ from that produced by other comigrating immunogens.

Consistently with recent studies, ${ }^{7810}$ however, these data show that the $\mathbf{3 7 0 0 0}$ dalton recombinant protein called $\mathbf{P} 2^{*}$ does represent a prominent immu- nogenic surface component (figs 3 and 4). The fact that a similar protein was found to be synthesised by $T$ pertenue but not by the avirulent spirochaete, $T$ phagedenis biotype Reiter (data not shown), supports the idea that $\mathrm{P}^{*}$ and other molecules, such as the adhesins ${ }^{30}$ are virulence markers for these pathogens.

The initial data, which show by immunoblot the 
relative absence of antibodies to $\mathrm{P}^{*}$ protein in patients with secondary and latent syphilis in contrast to those with primary syphilis, suggest that the recombinant protein may allow selective and discriminatory diagnosis of primary syphilis. The lack of circulating antibodies to this treponemal surface component during systemic infection (secondary syphilis) is in itself intriguing, and it will be interesting to assess whether purified $\mathbf{P} 2^{*}$ exhibits any immune modulating properties in experimental animals. ${ }^{6}$

These data illustrate the need for future studies of the structure and function of $\mathrm{P}^{*}$ and the other recombinant proteins (fig 1 ) to define the biological properties of the pathogen specific surface components. Isolation of $\mathrm{P}^{*}$ and other cloned treponemal gene products described in this report may facilitate an evaluation of cellular immune responses to select antigens and perhaps elucidate, at a molecular level, the influence of humoral and cellular immunity on the pathogenesis of syphilis.

We thank Diana Hinojosa for her superb secretarial assistance, Earline Morse for her technical expertise, and Luann Ray for her support and advice.

This work was supported by grant AI-19566 from the National Institutes of Health of the US Public Health Service and by a grant from Cistron Technologies Inc. JFA is recipient of an NIH Research Career Development Award KO4 AI-00584, and KMP was supported by NIH Training Grant T32 AI-07271.

\section{References}

1 Bishop NH, Miller JN. Humoral immunity in experimental syphilis. I. The demonstration of resistance conferred by passive immunization. J Immunol 1976;117:191-6.

2 Cannefax GR. Immunity in syphilis. British Journal of Venereal Diseases 1965;41:260-74.

3 Musher DM, Schell RF. The immunology of syphilis. Int J Dermatol 1976;15:566-73.

4 Perine PL, Weiser RS, Klebanoff SF. Immunity to syphilis: passive transfer in rabbits with hyperimmune serum. Infect Immun 1973;8:878-90.

5 Titus RG, Weiser RS. Experimental syphilis in the rabbit. Passive transfer of immunity with immunoglobulin $\mathrm{G}$ from immune serum. J Infect Dis 1979;140:904-13.

6 Folds JD. Cell-mediated immunity. In: Shell, RF, Musher DM, eds. Pathogenesis and immunology of treponemal infection. New York: Marcel Dekker, 1983:315-30.

7 Alderete JF, Baseman JB. Analysis of serum IgG against Treponema pallidum protein antigens in experimentally infected rabbits. British Journal of Venereal Diseases 1981;57:302-8.

8 Hanff PA, Bishop NH, Miller JN, Lovett MA. Humoral immune responses in experimental syphilis to polypeptides of Treponema pallidum. J Immunol 1983;131:1973-80.

9 Hanff PA, Miller JN, Lovett MA. Molecular characterization of common treponemal antigens. Infect Immun 1983;40:825-31.
10 Lukehart SA, Baker-Zander SA, Gubish ER. Identification of Treponema pallidum antigens: comparison with a nonpathogenic treponeme. J Immunol 1982;129:833-40.

11 Marchitto KA, Jones SA, Schell RF, Holmans PL, Norgard MV. Monoclonal antibody analysis of specific antigenic similarities among pathogenic Treponema pallidum subspecies. Infect Immun 1984;45:660-8.

12 Robertson SM, Kettman JR, Miller JN, Norgard MV. Murine monoclonal antibodies specific for virulent Treponema pallidum (Nichols). Infect Immun 1982;36:1076-85.

13 Fieldsteel AH, Becker FA, Stout JG. Prolonged survival of virulent Treponema pallidum (Nichols strain) in cell-free and tissue culture systems. Infect Immun 1977;18:173-81.

14 Peterson KM, Baseman JB, Alderete JF. Isolation of a Treponema pallidum gene encoding immunodominant outer envelope protein P6, which reacts with sera from patients at different stages of syphilis. J Exp Med 1986;164:1160-70.

15 Norgard MV, Miller J. Cloning and expression of Treponema pallidum (Nichols) antigen genes in Escherichia coli. Infect Immun 1983;42:435-45.

16 Stamm LV, Bassford PJ Jr. Cloning and expression of Treponema pallidum protein antigens in Escherichia coli. DNA 1982; 1:329-33.

17 van Embden JD, van der Donk JH, van Eijk RV, et al. Molecular cloning and expression of Treponema pallidum DNA in Escherichia coli K-12. Infect Immun 1983;42:187-96.

18 Walfield AM, Hanff PA, Lovett MA. Expression of Treponema pallidum antigens in Escherichia coli. Science 1982;216:522-3.

19 Fehniger ET, Walfield AM, Cunningham TM, Radolf JD, Miller JN, Lovett MA. Purification and characterization of a cloned protease-resistant Treponema pallidum specific antigen. Infect Immun 1984;46:598-603.

20 Hayes NS, Muse KE, Collier AM, Baseman JB. Parasitism by virulent Treponema pallidum of host cell surfaces. Infect Immun 1977;17:174-81.

21 Alderete JF, Baseman JB. Surface characterization of virulent Treponema pallidum. Infect Immun 1980;30:814-23.

22 Baseman JB, Hayes EC. Molecular characterization of receptor binding proteins and immunogens of virulent Treponema pallidum. J Exp Med 1980;151:573-86.

23 Peterson KM, Baseman JB, Alderete JF. Treponema pallidum receptor binding proteins interact with fibronectin. J Exp Med 1983;157:1958-70.

24 Maniatis T, Fritsch EF, Sambrook J. Construction of genomic libraries. In: Molecular cloning: a laboratory manual. New York: Cold Spring Habor Laboratory, 1982:269-93.

25 Clarke L, Carbon J. A colony bank containing synthetic Col El hybrid plasmids representative of the entire Escherichia coli. genome. Cell 1976;9:91-6.

26 Alderete JF, Freeman-Shade L, Baseman JB. Immunodiagnostic test for detection of serum antibody to Treponema pallidum (syphilis): fibronectin as a capture vehicle for treponemal adhesins. J Immunol Methods 1985;84:365-71.

27 Silhavy TS, Berman ML, Enquist LW. DNA extraction from bacterial cells. In: Experiments with gene fusions. New York: Cold Spring Harbor Laboratory, 1984:137-9.

28 Johnson DA, Gautsch JW, Sportsman JR, Eider JH. Improved technique utilizing nonfat dry milk for analysis of proteins and nucleic acids transferred to nitrocellulose. Gene Analysis Techniques 1984;1:3-9.

29 Towbin H, Staehelin T, Gordon J. Electrophoretic transfer of proteins. Proc Natl Acad Sci USA 1979;76:4350-4.

30 Baseman JB, Hayes EC. Molecular characterization of receptor binding proteins and immunogens of virulent Treponema pallidum. J Exp Med 1980;151:573-86. 